challenges of modernity and spiritual culture: finding the ways of interaction at the turn of the millennium]. Current issues of culturology. Almanac of the Scientific Society "Athena" of the Department of Cultural Studies. Vol. 8. pp. 6-10. [in Ukrainian].

4. Havrysh, N. \& Linnyk, O. (2014). Filosofiia dlia ditei: metodychnyi posibnyk [Philosophy for children: a textbook]. Kyiv, 232 p. [in Ukrainian].

5. Honcharenko, S. (1997). Ukrainskyi pedahohichnyi slovnyk [Ukrainian pedagogical dictionary]. Kyiv, 206 p. [in Ukrainian].

6. Ospadova, L.L. (2015). Rozvytok komunikatyvnykh navychok u ditei doshkilnoho viku za dopomohoiu suchasnykh dozvillievykh resursiv [Development of communication skills in preschool children with the help of modern leisure resources]. Stan ta perspektyvy rozvytku kulturolohichnoi nauky $v$ Ukraini. Materialy Vseukrainskoi naukovo-praktychnoi konferentsii - State and prospects of development of culturological science in Ukraine. Proceedings of the All-Ukrainian ScientificPractical Conference. Mykolaiv, 280 p. [in Ukrainian].

7. Partsialna prohrama z rozvytku sotsialnykh navychok efektyvnoi vzaiemodii ditei vid 4 do 6-7 rokiv "Vchymosia zhyty razom" [Partial program of the development of social skills of effective interaction of children aged from 4 to 67 years "Learning to live together"]. (Eds.). Pirozhenko T.O., Khartman O.Iu. Kyiv, 2016. 32 p. [in Ukrainian].

8. Pirozhenko,T.O. \& Khartman, O.Iu. (2014). Vykhovuiemo dytynu - zrostaiemo yak batky: navchalno-metodychnyi posibnyk [Raising a child growing up as parents: a textbook]. Ternopil, $168 \mathrm{p}$. [in Ukrainian].

Стаття надійшла до редакції 22.12.2020

УДК 78:398(477.81/.82)

DOI:

Вікторія Прокопчук, кандидат педагогічних наук, дочент кафедри гри на музичних інструментах Інституту мистеитв Рівненського державного гуманітарного університету

\title{
МИСТЕЦЬКЕ КРАСЗНАВСТВО ЯК НАУКОВА ПРОБЛЕМА (екскурси в історію вивчення фольклору Волині)
}

У статті здійснено екскурс в історію досліджень фольклору Волині як підгрунтя становлення мистецького краєзнавства краю у трансдисииплінарному векторі. Акиент зроблено на історіографіi досліджень музичного фольклору краю. Вивчення мистецького фольклору є невід'ємним складником мистеиького краєзнавства як науки і сфери пізнання фольклору різних видів мистецтва, щэо, крім музичного, охоплюе фольклор танцювальний, театральний, усну поетичну творчість, декоративно-ужиткове мистецтво тощо, історіографія яких потребує окремого розгляду в контексті становлення краєзнавчої науки.

Ключові слова: фольклор; музичний фольклор; краєзнавство; мистечьке краєзнавство; фольклор Волині. Лim. 16.

Victoriia Prokopchuk, Ph.D.(Pedagogy), Associate Professor of the Playing Musical Instruments Department of the Institutes of Arts, Rivne State University of Humanities

\section{ART LOCAL STUDIES AS A SCIENTIFIC PROBLEM (historic aspects of studying the folklore of Volyn region)}

The purpose of the article is to make a brief excursion into history of studying folk culture of Volyn region as the basis of art local studies of this land. The methodology of study is based on the use of different methods analytical, descriptive and chronological, historical and arts. The history of art formation in Volyn region can be analyzed with using these methods in trans-disciplinary vector. Scientific novelty. The scientific novelty of the work is in systematization of historical, encyclopedia reference, folklore and synthetic data concerning to different kinds of Volyn folklore. The studying of historiography of Musical Volyn folklore is emphasized.

Local studies are the treasure of age-old traditions, historical experience of generations and nationalcultural memory. Past, present and future are combined by the melody of folk song and native language. Art local studies explore the origins of Ukrainian mentality and spirituality. The formation of imagination about the fate of nation, development of patriotic and national consciousness is through the study of culture and history of "little homie". Local history studies, particularly cultural and artistic in this cultural-histirical and artistic research through the prism of thinking and learning from the experience are very important. Systematic studying of art local studies as a synthesized and holistic phenomenon of Ukrainian region of Volyn has not been submitted by scientists yet.

Studying of art folklore is an integral part of art local studies as a science. The sphere of folklore learning of different kinds of art includes dance and theatrical folklore, poetic creativity and decorative applied arts. Their 
historiography needs special consideration in the context of science formation and systematization on the new stage of generalization.

Keywords: folklore; musical folklore; local studies; art studies; folklore of Volyn region.

П остановка проблеми. Актуалізація вивчення фольклору й становлення мистецького краєзнавства пов'язана 3 процесами самоствердження нації, виокремленням унікальності культур та пошуків можливостей міжкультурної толерантності. У цьому контексті зростає значущість не лише вивчення фольклору як такого, а й саме у регіональному, краєзнавчому контексті.

Аналіз основних досліджень і публікацій з теми свідчить, що окремі види фольклору досить системно вивчаються фольклористами й мистецтвознавцями, а саме музичний фольклор постав предметом уваги в дослідженнях I. Збир, А. Іваницького, З. Лановик, М. Лановик, М. Мушинки та ін. Безпосередньо фольклор Волині висвітлено в дослідженнях В. Ковальчука, О. Ошуркевича, Б. Прищепи, О. Прищепи, Б. Столярчука, С. Шевчука та ін. Однак системний погляд на фольклор як цілісне явище Волині, передусім як синтезований феномен, ученими поки не представлений.

Мета статті - здійснити екскурси в історію досліджень фольклору Волині як підгрунтя становлення мистецького краєзнавства цього краю.

Виклад основного матеріалу. Звернімося до поняття “фольклор” і розглянемо його дослідження у системі музичного краєзнавства. Увагу акцентуватимемо на наукових розвідках стосовно волинського фольклору.

Як відомо, термін “фольклор” був введений до наукового обігу 1846 р. англійським археологом В. Томсоном у статті "Folk-Lore" для позначення проявів духовного життя народу - легенд, звичаїв, вірувань, обрядів, балад, прислів'їв давніх часів $[1,13]$. В українське народознавство термін був запроваджений М. Драгомановим та I. Франком $[1,16]$.

Історія збирання українських фольклорноетнографічних матеріалів бере початок від запису пісень, зокрема балади про С. Воєводу “Дунаю, Дунаю, чому смутен течеш" у “Чеській граматиці” Я. Благослава (XVI ст.) [11]. У 1827 р. український фольклорист, історик М. Максимович (1804-1873) зібрав I видання українських народних пісень, де підкреслив їх виховне значення, фольклор розглядав як засіб пізнання культури народу [8, 42].

Українським істориком, етнографом $M$. Костомаровим (1817-1885) 1859 р. видана збірка пісень, зібраних на Волині, що містить понад 200 зразків із коментарями дослідника. У с. Пляшева Рівненської обл. етнограф записав пісню, у якій відтворено події Берестецької битви 1651 р. [14, 327].

Крім вітчизняних етномузикознавців, народну музику в Україні записували іноземні науковці, яких цікавило в нашій культурі специфічне: багатоголосся, розмір, ритміка тощо.

Так, цікавою постаттю є 3. Доленга Ходаковський (1784-1825), польсько-український фольклорист, етнограф, який, мандруючи Волинню, Поліссям, збирав фольклорно-етнографічні матеріали, проводив археологічні дослідження. Зібрані близько 2000 українських, понад 1000 білоруських, польських народних пісень опубліковано у працях “Про слов'янство перед християнством” (1818), “Про галицькі пісні” (1829), “Українські народні пісні в записах 3. Доленги-Ходаковського” (1974). У 1814-1818 pр. працював у бібліотеці Кременецького ліцею $[12 ; 14,321]$.

Польський письменник, фольклорист, історик M. Грабовський (1804-1863) народився у с. Золотіїв (м. Рівне). Автор творів про життя, культуру українців як носіїв первісної слов'янської самобутності - роман “Тайкури: народна повість” (1845-1846); статті “Українські мелодії” (1828), “Про українські пісні” (1837); “Про українські народні легенди” (1845) [14, 319].

Яскравий слід у волинському краєзнавстві залишив польський письменник, етнограф Ю. Крашевський (1812-1887). Понад 20 років, найбільш плідних у творчому плані, мешкав на Волині. У 1838 р. оселився в с. Омельне, 1840 р. купив с. Городок Рівненської обл. У 1853 р. переїхав до центру польського життя на Волині м. Житомира, де працював попечителем шкіл; директором Волинського театру, де ставилися його твори; начальником статистичного комітету, що дозволило відновлювати пам'ятки архітектури й мистецтва; заснував Житомирську бібліотеку. Спадщина становить близько 600 творів, серед яких праці з етнографії, фольклористики, мистецькі статті. Твори містять етнографічні матеріали про життя, традиції, побут волинян: “Спогади з Волині, Полісся і Литви” (“Wspomnienia Wołynia, Polesia i Litwy”, 1840), "Волинські вечори” (1859) та ін. [3, 307-310; 14, 328-329].

Чимало записів волинського фольклорного надбання належить польському фольклористові, композитору О. Кольбергу (1814-1890), який у 1856-1880 рр. досліджував етнографію, фольклор Волині, Полісся. На Рівненщині записав понад 
30 пісень, що вміщені у працях “Казка з Полісся”, "Весільні звичаї та обряди з Полісся”, “Покуття” (1889), “Волинь” (1907). Повне видання творів 70 т. видано у Польщі (1961-1980) [14, 325-326].

Волинь дослідник відвідав упродовж двох місяців 1862 р., де зафіксував понад кількасот народних мелодій, пісень, звичаїв, обрядів. Учений також записував українські народні пісні у Польщі, де проживали вихідці з України. Фольклорно-етнографічна праця “Волинь" містить матеріали з Волинської, Рівненської, Житомирської, Тернопільської, Хмельницької та ін. обл. Робота над монографією тривала до кінця його життя та видана була лише через 27 років після смерті. Праця складається з двох розділів: “Західна Волинь” (“Wołyń zachodni”) та “Східна Волинь” (“Wołyń wschodni”). I розділ містить 3 описи весільного обряду, тексти 627 пісень із музикою та п'ять мелодій, записаних етнографом. 25 українських казок (“казок люду руського”) II p. зібрані 1835 р. Завдяки праці Польського народознавчого товариства у Вроцлаві, де зберігається його рукописна спадщина, Інституту ім. О. Кольберга у Познані, 2002 р. світ побачив додатковий том монографії. “Волинь” стала не лише явищем у діяльності польського вченого як дослідника української народної творчості, а й у розвитку української фольклористики та етнографії [4].

3 Волинню пов'язаний родовід фольклориста, поета П. Чубинського (1839-1884). Прадіди Казимир та Франц (Павло) під прізвищем Чуб родом з с. Перемилівка (Рівненщина). У 1869 1870 рр. очолював експедицію під орудою Російського географічного товариства зі збагачення фольклорно-етнографічного досвіду на Рівненщині. Упродовж двох років науковці вивчали 56 повітів України (У т.ч. Волині), Білорусі тощо. На Волині обстежувалися 10 повітів. Видано матеріал у "Працях етнографічностатистичної експедиції Західноруського краю, спорядженої Імператорським Російським Географічним Товариством. Південно-Західний відділ. Матеріали і дослідження, зібрані П. Чубинським" у 7 т. (1872-1878). Праця містить близько 4000 обрядових пісень, 300 казок, звичаїв, приказок, легенд, прикмет, понад 60 обрядів родин, хрестин, весіль тощо, а також опис побуту, карти говорів та етнографічно-статистичні матеріали щодо національних меншин в Україні (поляків, євреїв, німців, чехів) [14, 345; 16].

Примітно, український історик, літературознавець, фольклорист М. Драгоманов (1841-1895), будучи відрядженим Київським університетом за кордон, у 1870 р. бував на Рівненщині (Рівне, Корець,
Дубно, Радивилів), де досліджував фольклор, проводив історичні розвідки Волині [14, 321-322].

Як відомо, письменниця, етнограф О. Пчілка (1849-1930), мешкаючи на Волині, систематизувала фольклор краю. Зокрема, перебуваючи 1879 р. 3 Лесею Українкою у с. Чекно Рівненської обл. записувала пісні, обряди, звичаї, збирала зразки народних вишивок й художніх візерунків [14, 336].

Російський етнограф, співробітник Імператорського Російського географічного товариства $B$. Мошков (1852-1922) вивчав побут, традиції, специфіку волинської культури. Так, у 1891 р. записав для Городоцького музею барона Ф. Штейнгеля пісні 3 нотним текстом від солдат Варшавського гарнізону, 15 я яких зберігаються у фондах Державного архіву Рівненської обл. Фіксував фольклорно-етнографічний матеріал у с. Великі Цепцевичі Рівненської обл. (1899), створив “Вертеп” з текстом, музикою (1896) [14, 332].

Нагадаємо, що велика фольклористична праця зроблена письменницею Лесею Українкою (1871-1913), яка народилася у м. НовоградВолинський, чверть століття життя провела на Волині, де досліджувала фольклор. У Колодяжному було занотовано кількасот пісень народних, цикл “Купала на Волині” (1893) тощо. 1902 р. видано “Дитячі ігри, пісні та казки 3 Ковельщини, Луччини та Звягельщини”, що містять шість ігор, мирилку, безкінечник, чотири пісеньки, три казки з приспівками та оповідання “Приязнь”, де описано життя волинського Полісся (1905). У 1908 р. заходами К. Квітки, Ф. Колесси та О. Сластіона було записано народні думи від кобзарів та лірників “Мелодії українських народних дум" (1910-1913), редагуванням яких займався Ф. Колесса. Легенди, звичаї Волині поетеса увічнила у драмі-феєрії “Лісова пісня" (1911). На поч. ХХ ст. К. Квіткою записано відомі їй народні пісні (понад 220 зразків) та видано двома випусками під назвою “Народні мелодії з голосу Лесі Українки” $(1917,1918)$ [10; $14,342]$.

Як відомо, музикознавцем, фольклористом К. Квіткою (1880-1953) було зібрано понад 6000 українських й кілька сотень білоруських, румунських, молдавських, російських пісень та інструментальної музики. У 1931 р. записував пісні на Волинському Поліссі. Наукова спадщина містить теоретичні розробки з методології дослідження календарних пісень та інструментальної традиції. За життя видав понад 40 досліджень 3 музичного фольклору, збірників народної музики. Записував український мелос 3 голосу Лесі Українки та I. Франка. Вершиною етнографічного шляху є збірник “Українські народні мелодії' 
(1922), що підсумував 25-річну роботу й містить 743 пісні [5; 14, 323].

Народні музично-поетичні скарби Волинського,

Рівненського краю досліджував засновник українського етнографічного музикознавства, фольклорист, композитор Ф. Колесса (1871-1947). У 1937 р. разом з Рівненським дослідником Ю. Цехміструком записував пісні на Поліссі, Волині. Фольклор Полісся відображений у праці “Ритміка українських народних пісень” (1907), “Народна музика на Поліссі” (1939) [5; 14, 325].

Документаліст волинського народного мистецтва Ю. Цехмійструк (1895-1968) народився у Волинській губернії. Працював учителем шкіл Рівненщини, інспектором народних хорів Волинського воєводства, учителем співу у Рівненській українській гімназії ім. Т. Шевченка та музичної школи ім. М. Лисенка. Об'їхав із фонографом 50 місцевостей Волинського воєводства, записав понад 700 творів вокальноінструментальної народної музики від більш ніж 150 виконавців. Уклав пісенник хорових обробок "Wolyn" (Katowice, 1938). Фольклористичний доробок 1936-1937 рр. складає два зошити картотеки нотних транскрипцій 3 текстами та слугує джерелом збереження, дослідження, популяризації Волинського музичного надбання. На поч. 30-х рр. ХХ ст. брав участь у конкурсі серед учителів на записування волинських народних мелодій, матеріали (понад 500 зразків) видав у збірнику “Волинські народні пісні” (1937). Як підсумок конкурсу, збірку видав і Ф. Колесса, що містила обробки пісень 3 Рівненського, Кременецького, Дубенського, Луцького повітів $[14,344 ; 15]$.

Великий внесок у розбудову Волинського краєзнавства зробив фольклорист, етнограф, музеєзнавець $B$. Кравченко (1862-1945), один із засновників етнографічної секції Товариства дослідників Волині у Житомирі (1900), один 3 перших теоретиків етнографічної музейної справи в Україні. В “Етнографічних матеріалах", "Працях Товариства дослідників Волині” видав народознавчий матеріал, записаний у Корці, Острозі та ін. місцевостях краю (пісні, звичаї, легенди). Займався музейницько-просвітницькою діяльністю у м. Житомир: сприяв заснуванню Музею Товариства дослідників Волині (1913), де завідував етнографічним відділом; був одним 3 організаторів "Просвіти”. Засновував краєзнавчі гуртки у Житомирі, створював музейні осередки на Волині, при яких організував аспірантуру й виховував музейних працівників. У педагогічному технікумі м. Житомир прочитав понад 800 лекцій 3 краєзнавства. Впроваджував програму етнографічного дослідження Волині, до якої залучав учителів та молодь. Вивчав культуру українську й національних меншин краю [9; 14 , $328]$.

Примітно, що етнограф, музейний діяч М. Біляшівський (1867-1926) понад 10 років (1895-1914) перебував у с. Городок Рівненської обл., де брав участь у заснуванні, розбудові музею барона Ф. Штейнгеля. У 1890-1917 pр. збирав народні пісні, легенди, пам'ятки Волині. Уклав українсько-російські діалектичні словники волинських говірок, що зберігаються в бібліотеці НАН України та в Музеї етнографії у СанктПетербурзі [2, 295; 14, 318].

Особливу цінність складає народознавча діяльність фольклориста, літературознавця, одного із засновників Товариства дослідників Волині М. Коробки (1872-1922). Вивчав етнографію Волинського Полісся, зібрав на Волині фольклорні матеріали, що видані у працях "Пісні Кам'янецького повіту Подільської губернії” (1895), “Колядки та щедрівки, записані у Волинському Поліссі" (1902), зібрані в Житомирському, Новоград-Волинському, Луцькому повітах Рівненської обл. Праці “Весняна гра - пісня “Воротар", “Пісня про князя Романа” (1899), “До вивчення малоруських колядок” (1902) присвячені питанням зв’язку народної поезії з обрядами та життям народу [7; 14, 326].

Цінною народознавчою знахідкою історика, фольклориста В. Доманииького (1877-1910), одного із засновників видавництва "Вік” (18951918), редактора першого “Кобзаря” Т. Шевченка (1907), дослідника творчості 3. ДоленгиХодаковського, є фіксація на Рівненщині оригінального тексту “іменної співанки” на честь свята Теплого Олексія та звичаю справляти Колодія (колодку) на Масляну (“Народний календар в Рівненському повіті Волинської губернії”, Львів, 1912) [14, 321].

Велику роль займає педагогічно-просвітницька діяльність композитора, дослідника традиційної музичної культури Волині С. Козицького (18831941). Очолював товариство “Просвіта", ансамбль народних інструментів, світський та церковні хори, викладав у церковнопарафіяльних школах, видав підручник для школярів, що зберігається в Державному історико-культурному заповіднику Дубна. Відродив та впровадив у побут вертепні різдвяні драми. Пісенно-обрядовий фольклор, пісні інших народів, зібрані на поч. XX ст., містяться у працях "Народні пісні Волині, Поділля і Холмщини” (2014), “Сивий туман на долині” (1998) [6].

У 30-х рр. ХХ ст. організатором краєзнавчої 
роботи у м. Рівне був польський культурноосвітній діяч, краєзнавець Я. Гофман (1896-1964), який 20 років присвятив дослідженню Волині. Рівненський період, куди прибув 1923 р. для організації відділу позашкільної освіти, є найбільш плідним. Працював учителем, директором школи (1923-1940), головою Рівненського правління Спілки польських вчителів (1927-1939), уповноваженим з державної охорони доісторичних пам'яток Волинського воєводства (1924), очолював крайову спілку вчителів польських шкіл (1923-1935), створив музей господарства Волині (1936-1939). Займався політичною діяльністю (посол польського сейму), цікавився етнографією, геральдикою, історією Волині. Справою життя стало створення першого на Волині краєзнавчого видання "Рочник Волинський” (“Rocznik Wołyński”), який виходив у Рівному (1930-1939) та містив статті з усіх ділянок знання про Волинь (етнографія, фольклор). Зібрав понад 100 зразків вишиванок та волинських писанок, що зберігаються у Волинському краєзнавчому музеї $[13,101-103]$.

У XX ст. особливий внесок у розбудову Волинського мистецького краєзнавства зробили письменник, I голова Рівненської організації Національної спілки краєзнавців України I. Пащук (1938-2013); краєзнавець, журналіст Г. Дем'янчук (1936-2001); краєзнавець, історик Г. Бухало (1932-2008) та ін. Цінною є краєзнавча діяльність мистецтвознавця Б. Столярчука (1947); директора Рівненського краєзнавчого музею О. Булиги (1965) та ін.

Потужним осередком у реаліях відродження фольклорної культури краю є Етнокультурний центр “Веснянка” Рівненського міського Палацу дітей та молоді, у структурі якого діють Лабораторія поліського фольклору, Школа традиційної народної культури та три колективи. У навчальних підрозділах Центру культуру Полісся вивчає понад 200 дітей області. На чолі 3 дослідником фольклору, засновником центру "Веснянка" В. Ковальчуком учасники займаються пошуковою, виконавською діяльністю.

Висновки та перспективи подальших досліджень. У статті окреслено історіографію досліджень переважно музичного фольклору Волині. Проте мистецький фольклор як невід'ємний складник мистецького краєзнавства містить фольклор танцювальний, театральний, усну поетичну творчість, декоративно-ужиткове мистецтво, історіографія яких потребує окремого розгляду в контексті становлення краєзнавчої науки та систематизації на новому щаблі узагальнення.

\section{ЛІТЕРАТУРА}

1. Глушко М. Фольклор: початок вживання терміна в українській науці та його значення. Нар. творчість та етнографія. 2008. № 6. С. 12-23.

2. Енциклопедія історії України : у 10 т. / Ін-т історії України НАН України; редкол.: В. А. Смолій (гол.) та ін. Київ : Наук. думка, 2003. Т. 1: А”В. 688 с.

3. Енциклопедія історії України : у 10 т. / Ін-т історії України НАН України ; редкол.: В. А. Смолій (гол.) та ін. Київ : Наук. думка, 2008. Т. 5: Кон”Кю. 568 с.

4. Збир І. Історія написання збірника "Волинь. Обряди, мелодії, пісні” Оскара Кольберга. Мандрівець : наук. журн. / Нац. ун-т "КиєвоМогилянська академія”. Тернопіль. 2013. № 3. C. $54-58$.

5. Іваницький А. Українська народна музична творчість : посіб. для вищ. та серед. учбов. закл. Київ : Муз. Україна, 1990. 366 с.

6. Козицький С. О. Народні пісні Волині, Поділля і Холмщини / ред.-упоряд. Б. Столярчук, О. Юзюк. Рівне : О. Зень, 2014. 128 с.

7. Костриця М. Ю. Товариство дослідників Волині: історія, діяльність, постаті. Житомир : М. А. К., 2001. 360 c.

8. Лановик М., Лановик 3. Українська усна народна творчість : підручник. Київ : ЗнанняПрес, 2001. 591 c.

9. Лобода Т. М. Василь Кравченко. Громадська, наукова та просвітницька діяльність. Київ : ІПіЕНД ім. І. Ф. Кураса НАН України, 2008. 238 с.

10. Мержвинська Л. Леся Українка жити без Волині не могла. Вісник. 25.02.2006 p. URL: http:/ /visnyk.lutsk.ua/news/ukraine/regions/volyn/1019/.

11. Мушинка М. “Дунаю, Дунаю, чому смутен течеш?” : нове про історію дослідження і місцезнаходження найдавнішого запису української народної пісні. Нар. творчість та етнографія. 2000. № 2-3. С. 3-16.

12. Ошуркевич О. Зоріан Доленга-Ходаковський і Волинь: до народнопісенних джерел. Минуле $i$ сучасне Волині: історичні постаті краю : тези доп. та повідомл. V Волин. іст.-краєзн. конф., $11-$ 13 жовт. 1991 р. / Луцький держ. пед. ін-т ім. Лесі Українки, Волин. обл. т-во краєзнавців ; редкол.: Р. А. Арцішевський та ін. Луцьк, 1991. С. 51-58.

13. Прищепа О., Прищепа Б. Якуб Гофман організатор досліджень історії та культури Волині. Етнокультурна спадщина Рівненського Полісся : наук. видання. Рівне : Перспектива, 2002. Вип. II. С. 101-103.

14. Столярчук Б. Й. Митці Рівненщини : енциклопед. довід. / ред.: Г. Дем'янчук, М. Підлипний. 1-ше вид. Рівне : Ліста, 1997. 366 с. 
15. Столярчук Б. Юрій Цехмійструк - збирач поліських пісень. Енергетика слова : рецензії, дослідження, нариси, статті. Рівне, 2012. С. 7983.

16.Шевчук С. Волиньународознавчихзацікавленнях Павла Чубинського. Поліссєзнавство у фольклорноетнографічних і літературно-мистецьких дослідженнях. Рівне : Волин. обереги, 2009. C. 15-25.

\section{REFERENCES}

1. Ghlushko, M. (2008). Folklor: pochatok vzhyvannia termina $\mathrm{v}$ ukrainskii nautsi ta yoho znachennia [Folklore: the beginning of the use of the term in Ukrainian science and its significance]. Nat. creativity and etnography, no. 6, pp.12-23. [in Ukrainian].

2. Smolii, V.A. (Ed.). (2003). Entsyklopediia istorii Ukrainy : 10 t. [Encyclopedia of Ukrainian History]. Vol. 1. Kyiv, 688 p. [in Ukrainian].

3. Smolii, V.A. (Ed.). (2008). Entsyklopediia istorii Ukrainy : u 10 t. [Encyclopedia of Ukrainian History]. Vol. 5. Kyiv, 568 p. [in Ukrainian].

4. Zbyr, I. (2013). Istoriia napysannia zbirnyka "Volyn. Obriady, melodii, pisni" Oskara Kolberha [The history of writing the collection "Volyn. Rites, melodies, songs" Oscar Kolberg]. Mandrivets: Science.magazine. No. 3, pp. 54-58. [in Ukrainian].

5. Ivanytskyi, A. (1990). Ukrainska narodna muzychna tvorchist : posib. dlia vyshch. ta sered. uchbov. zakl [Ukrainian folk musical creativity]. Kyiv, 366 p. [in Ukrainian].

6. Kozytskyi, S. O. (2014). Narodni pisni Volyni, Podillia i Kholmshchyny [Folk songs of Volyn, Podillya and Kholmshchyna]. (Eds.). B. Stoliarchuk, O. Yuziuk. Rivne, 128 p. [in Ukrainian].

7. Kostrytsia, M. Yu. (2001). Tovarystvo doslidnykiv Volyni: istoriia, diialnist, postati [Volyn Researchers Society: History, Activities, Figures]. Zhytomyr, 360 p. [in Ukrainian].

8. Lanovyk, M. \& Lanovyk, Z. (2001). Ukrainska usna narodna tvorchist : pidruchnyk [Ukrainian oral folk art]. Kyiv, 591 p. [in Ukrainian].

9. Loboda, T. M. (2008). Vasyl Kravchenko. Hromadska, naukova ta prosvitnytska diialnist. [Vasyl
Kravchenko. Public, scientific and educational activities]. Kyiv, 238 p. [in Ukrainian].

10. Merzhvynska, L. (25.02.2006). Lesia Ukrainka zhyty bez Volyni ne mohla [Lesia Ukrainka could not live without Volyn]. Herald. Available at: http:// visnyk.lutsk.ua/news/ukraine/regions/volyn/1019/ [in Ukrainian].

11. Mushynka, M. (2000). "Dunaiu, Dunaiu, chomu smuten techesh?" : nove pro istoriiu doslidzhennia i mistseznakhodzhennia naidavnishoho zapysu ukrainskoi narodnoi pisni. ["The Danube, the Danube, why is it vague?": A new story about the history and location of the oldest record of the Ukrainian folk song]. Nat. creativity and etnoghraphy, no. 2-3, pp.3-16. [in Ukrainian].

12. Oshurkevych, O. (1991). Zorian DolenhaKhodakovskyi i Volyn: do narodnopisennykh dzherel [Zorian Dolenga-Khodakovsky and Volhyn: to folkpopulated sources]. Mynule i suchasne Volyni: istorychni postati kraiu : tezy dop. ta povidoml. V Volyn. ist.-kraiezn. konf., 11-13 zhovt. 1991 r. - Past and present of Volyn: the historical figures of the region: Abstracts of Papers of the V Volyn. East-regional. Conf., Oct. 11-13. 1991 (pp.51-58). Lutsk. [in Ukrainian].

13. Pryshhepa, O. \& Pryshhepa, B. (2002). Yakub Hofman - orhanizator doslidzhen istorii ta kultury Volyni [Yakub Hoffman is the organizer of studies on the history and culture of Volyn]. Ethnocultural heritage of Rivne Polissya: science. edition. Rivne, Vol. II. pp. 101-103.[in Ukrainian].

14. Stoliarchuk, B. Y. (1997). Myttsi Rivnenshchyny : entsykloped. dovid. [Artists of the Rivne region]. (Eds.). H. Demianchuk, M. Pidlypnyi. Rivne, 366 p. [in Ukrainian].

15. Stoliarchuk, B. (2012). Yurii Tsekhmiistruk zbyrach poliskykh pisen. [Yuri Tsekhmiystruk is a collector of Polissya songs]. Energy of the word: reviews, research, essays, articles. Rivne, pp. 79 83. [in Ukrainian].

16. Shevchuk, S. (2009). Volyn u narodoznavchykh zatsikavlenniakh Pavla Chubynskoho. [Volyn in the ethnographic interest of Pavel Chubinsky]. Polyssyeznavstvo in the folklore-ethnographic and literary-artistic researchers. Rivne, pp. $15-25$. [in Ukrainian].

\section{Стаття надійшла до редакції 18.11.2020}

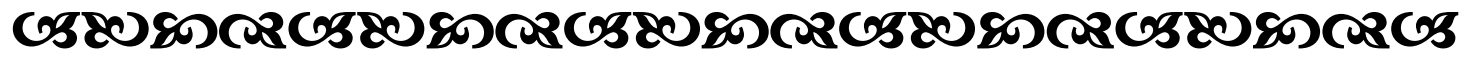

“Теред людиною три шляхи до розуму: шлях мірқування - найиляхетніший; шлях наслідування - найлегший; шлях особистого досвіду - найважиий”.

\section{G58080}

